\title{
Infralimbic EphB2 Modulates Fear Extinction in Adolescent Rats
}

\author{
Emmanuel Cruz, ${ }^{1}$ Omar Soler-Cedeño, ${ }^{1}$ Geovanny Negrón, ${ }^{2}$ Marangelie Criado-Marrero, ${ }^{1}$ Gladys Chompré, ${ }^{2}$ \\ and James T. Porter ${ }^{1}$ \\ ${ }^{1}$ Department of Basic Sciences, Ponce Health Sciences University-School of Medicine/Ponce Research Institute, Ponce, Puerto Rico 00732, and \\ ${ }^{2}$ Department of Biology, Pontifical Catholic University of Puerto Rico, Ponce, Puerto Rico 00717
}

\begin{abstract}
Adolescent rats are prone to impaired fear extinction, suggesting that mechanistic differences in extinction could exist in adolescent and adult rats. Since the infralimbic cortex (IL) is critical for fear extinction, we used PCR array technology to identify gene expression changes in IL induced by fear extinction in adolescent rats. Interestingly, the ephrin type B receptor 2 (EphB2), a tyrosine kinase receptor associated with synaptic development, was downregulated in IL after fear extinction. Consistent with the PCR array results, EphB2 levels of mRNA and protein were reduced in IL after fear extinction compared with fear conditioning, suggesting that EphB2 signaling in IL regulates fear extinction memory in adolescents. Finally, reducing EphB2 synthesis in IL with shRNA accelerated fear extinction learning in adolescent rats, but not in adult rats. These findings identify EphB2 in IL as a key regulator of fear extinction during adolescence, perhaps due to the increase in synaptic remodeling occurring during this developmental phase.
\end{abstract}

Key words: adolescent; amygdala; EphB2; extinction; medial prefrontal cortex

\section{Introduction}

Symptoms of post-traumatic stress disorder (PTSD) can develop in children and adolescents who have been exposed to traumatic events, such as natural disasters, assaults, rape, and war. This population often finds it difficult to forget their childhood traumas during adulthood (Ahrens and Rexford, 2002; Berger et al., 2007; Berger and Gelkopf, 2009). Although, a recent study (Gilboa-Schechtman et al., 2010) showed that prolonged exposure therapy can significantly improve the symptoms of PTSD in adolescents, $>30 \%$ of the adolescents continued to meet the diagnostic criteria for PTSD post-treatment. Since early life traumas increase the probability of PTSD development after traumatic events in adults (Koenen et al., 2007), improving the outcomes of exposure therapy in adolescents could reduce the development of PTSD in adulthood. Using pavlovian fear extinction (EXT) in rats to mimic exposure therapy in humans, it was found that fear extinction memory in adolescent rats is less robust than in adult rats (McCallum et al., 2010; Pattwell et al., 2012). This finding suggests that fear extinction in

\footnotetext{
Received 0ct. 14, 2014; revised July 13, 2015; accepted July 23, 2015.

Author contributions: E.C. and J.T.P. designed research; E.C., O.S.-C., G.N., M.C.-M., and G.C. performed research; E.C., O.S.-C., G.N., M.C.-M., and G.C. analyzed data; E.C. and J.T.P. wrote the paper.

This work was supported by NIH Grants R36 1R36MH102080 to E.C., MBRS-RISE 1R25 GM 082046 to 0.S.-C. and M.C.-M.; and G12MD007579 and R15 MH101700 to J.T.P. We thank Dr. Annelyn Torres-Reveron for statistical consultation.

The authors declare no competing financial interest.

Correspondence should be addressed to Dr. James T. Porter, Department of Basic Sciences, Ponce Health Sciences University-School of Medicine/Ponce Research Institute, P0 Box 7004 Ponce, Puerto Rico 007327004.E-mail: jporter@psm.edu.

DOI:10.1523/JNEUROSCI.4254-14.2015

Copyright $\odot 2015$ the authors $\quad 0270-6474 / 15 / 3512394-10 \$ 15.00 / 0$
}

adolescents and adults may involve different molecular mechanisms.

Molecular changes underlying fear extinction can occur in the amygdala, hippocampus, or medial prefrontal cortex (mPFC; Quirk and Mueller, 2008; Mahan and Ressler, 2012; Maren et al., 2013). Since reduced fear extinction in adolescents involves a reduced activation of infralimbic cortex (IL; Kim et al., 2011), it is likely that gene expression changes in IL, which mediate consolidation of extinction memory, may be different during adolescence. However, previous studies found that fear extinction in both adolescents and adults depends on IL signaling via NMDA receptors (Burgos-Robles et al., 2007; Sotres-Bayon et al., 2009; McCallum et al., 2010), mGluR5 receptors (Fontanez-Nuin et al., 2011; Sepulveda-Orengo et al., 2013), and ERK (Hugues et al., 2006; Kim et al., 2011), suggesting that similar mechanisms within IL encode fear extinction in both adolescents and adults.

To identify additional mechanisms mediating fear extinction plasticity in IL during adolescence, we first used an unbiased PCR array approach to identify changes in synaptic plasticity-related genes in IL induced by fear extinction in adolescent rats. Two groups that showed normal (low freezing at the end of the extinction session) or impaired extinction (high freezing at the end of the session) were compared to identify novel molecules critical for fear extinction-induced plasticity. Interestingly, ephrin type B receptor 2 (EphB2), a tyrosine kinase receptor, was downregulated in IL after a successful extinction session. Although most studies involving EphB2 are related to neuronal development (Flanagan and Vanderhaeghen, 1998; Gao et al., 1999; Elowe et al., 2001; Cramer et al., 2006; Kayser et al., 2006, 2008, 2011; Nishimura et al., 2006; McClelland et al., 2010; Srivastava et al., 2013), EphB2 also contributes to synaptic plasticity (Dalva et al., 2000; Grunwald et al., 2001; Takasu et al., 2002; Lai and Ip, 2009; 


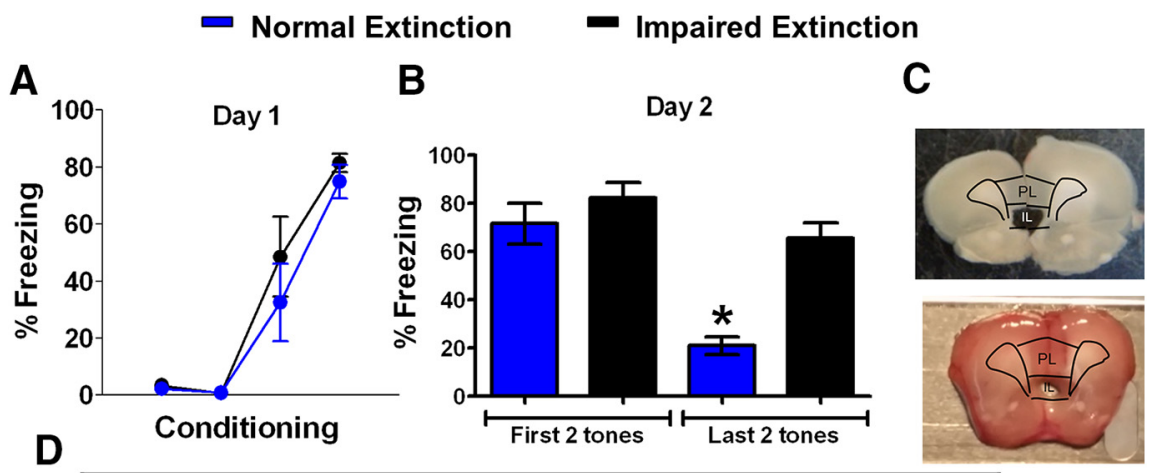

\begin{tabular}{|c|c|c|c|c|c|c|c|}
\hline \multicolumn{7}{|c|}{ Normal/Impaired } \\
\hline AMPAR & FC & NMDAR & FC & mGluR & FC & Other & FC \\
\hline GluA1 & -1.32 & NR1 & -1.15 & Grm1 & -1.23 & PICK1 & -1.15 \\
\hline GluA2 & 1.32 & NR2A & -1.32 & Grm2 & -1.74 & BDNF & 1.07 \\
\hline GluA3 & -1.15 & NR2B & -1.00 & Grm3 & -1.32 & TrkB & -1.07 \\
\hline GluA4 & 1.07 & NR2C & 1.07 & Grm4 & 1.41 & CREB & 1.07 \\
\hline & & NR2D & -1.32 & Grm5 & -1.87 & EphB2 & -3.73 \\
\hline
\end{tabular}

Figure 1. Identification of EphB2 as a potential marker of successful fear extinction learning in IL. $A$, Percentage of time that rats spent freezing to the tone during fear conditioning (day 1 , one habituation tone plus three tone-shock pairings). $\boldsymbol{B}$, Average percentage freezing during the first and last two tones of extinction. Rats were divided into normal extinction learners (blue, $n=$ 5) and impaired extinction learners (black, $n=4$ ). Extinction training was given on day 2 and consisted of 15 tones. Both groups were euthanized $5 \mathrm{~h}$ after extinction. C, Samples of brain slices after removing IL with tissue puncher. D, Relative expression of various genes in the normal extinction group/impaired extinction group detected by a PCR array.

Antion et al., 2010; Hruska and Dalva, 2012). In addition, a recent study (Trabalza et al., 2012) showed that the expression of one of the EphB2 ligands, EphrinB2, is increased in the hippocampus after contextual fear conditioning (COND), suggesting that increased activation of EphB2 signaling may contribute to increased fear expression. However, the role of EphB2 in fear extinction is completely unexplored. In this study, we found that EphB2 expression decreases after fear extinction in IL and that reducing IL EphB2 expression facilitates fear extinction in adolescent but not in adult rats. Our findings suggest that reduced signaling via EphB2 in IL plays an important role in fear extinction memory during adolescence.

\section{Materials and Methods}

Subjects. The procedures were approved by the Institutional Animal Care and Use Committee of the Ponce Health Sciences University School of Medicine in compliance with the National Institutes of Health Guide for the Care and Use of Laboratory Animals. Male Sprague Dawley rats ( $\sim 30$ or $\sim 60 \mathrm{~d}$ postnatal) were transported from the Ponce Health Sciences University colony to a satellite facility nearby where they were housed in transparent polyethylene cages inside a negative-pressure clean room (BioBubble, Colorado Clean Room, Ft. Collins, CO). Rats were maintained on a $12 \mathrm{~h}$ light/dark schedule with free access to food (standard laboratory rat chow) and water.

Behavioral apparatus. Rats were fear conditioned, extinguished, and tested in a $25 \times 29 \times 28 \mathrm{~cm}$ chamber with aluminum and Plexiglas walls (Coulbourn Instruments). The floor consisted of stainless steel bars that deliver a mild shock. A speaker was mounted on the outside wall, and illumination was provided by a single overhead light. The chamber was situated inside a sound-attenuating box (Med Associates) with a ventilating fan that produced an ambient noise level of $60 \mathrm{~dB}$. The conditioned stimulus (CS) was a $4 \mathrm{kHz}$ tone with duration of $30 \mathrm{~s}$ and an intensity of $80 \mathrm{~dB}$. The unconditioned stimulus (US) was a $0.44 \mathrm{~mA}$ scrambled footshock, $0.5 \mathrm{~s}$ in duration, which coterminated with the tone during the conditioning phase. Between sessions, floor trays and shock bars were cleaned with soapy water and the chamber walls were wiped with a damp cloth. Behavior was recorded with digital video cameras (Micro Video Products).
Extinction behavioral procedure. For the mRNA and protein expression studies, rats received one habituation (one CS) tone and three tone-shock (three CS-US) pairings on day 1 (conditioning phase). On day 2 , rats received 0 , 1 , or 15 CSs, depending on the group. Rats that received no CSs on day 2 were euthanized $24 \mathrm{~h}$ after training on day 1 . Rats that received 1 or 15 CSs were euthanized $5 \mathrm{~h}$ after training on day 2. For the shRNA infusion experiments, rats received one habituation CS and three CS-US pairings on day 1 (fear-conditioning phase). After matching for equivalent levels of freezing, conditioned rats were divided into a control group (scramble-shRNA plasmid) and an experimental group (EphB2-shRNA plasmid). On days 2 and 3, rats were infused with control or experimental plasmids and remained in their home cages. On days $4-8$, rats received a partial extinction session of four CSs each day. After behavior, the infused animals were euthanized with an overdose of pentobarbital, and brains were removed and cut into $30 \mu \mathrm{m}$ slices to verify cannula placement. Fluorescent images were obtained using an Olympus light microscope and were merged with NIS Elements imaging software (Nikon).

PCR array and real-time PCR. IL and prelimbic cortex (PL) tissue was collected with a tissue punch and stored in Allprotect Tissue Reagent (catalog 76405 , Qiagen) at $-80^{\circ} \mathrm{C}$. IL tissue was lysed by pipetting. Then RNA was extracted using a RNeasy Micro Kit (catalog 74004 , QIAGEN) and stored at $-80^{\circ} \mathrm{C}$. This kit was used because it has the capacity of extracting RNA from small tissue samples such as from IL. RNA was quantified with a NanoDrop 2000 (Thermo Scientific). A $0.2 \mu \mathrm{g}$ sample of RNA was used for the rat synaptic plasticity PCR array (PARN-126Z, SABiosciences) or was converted into cDNA using an iScript cDNA Synthesis Kit (catalog 170-8890, Bio-Rad). was then diluted to a concentration of 1:20. The cDNA dilution underwent RT-PCR using iQ SYBR Green Supermix (catalog 170-8882, Bio-Rad). EphB2 primers were purchased from SABiosciences (catalog PPR55124A). Custom primers for B-actin and GAPDH were used as housekeeping controls (B-actin: forward, AAGTCCCTCACCCTCCCAAAA; reverse, AAGCAATGCTGTCACCTTCCC; GAPDH: forward, GATGCTGGTGCTGAGTATGT; reverse, GCGGAGATGACCCTT).

Protein analysis. IL tissue was collected and stored in RIPA buffer at $-20^{\circ} \mathrm{C}$. IL tissue was lysed by pipetting, and a Bradford assay was used to quantify protein by measuring the absorbance of our samples. One hundred micrograms of protein was immunoprecipitated overnight with rabbit anti-EphB2 antibody H-80 (1:50; sc-28980, Santa Cruz Biotechnology), Sepharose Protein A (PA50-00-0002) beads, and ELB buffer, as follows: $\mathrm{NaCl}$ (250 mM), HEPES (50 mM), EDTA (5 mM), NP-40 (0.1\%), DTT ( 1 M), aprotinin, leupeptin, Pafobloc, PMSF, NaPPi, $\mathrm{Na}_{3} \mathrm{VO}_{4}$, one tablet of PhosSTOP Phosphatase Inhibitor Cocktail (catalog 04906837001, Roche Life Science), and one tablet of Complete mini Protease Inhibitor Cocktail (catalog 04693116001, Roche Life Science). After overnight immunoprecipitation, the samples were loaded into a gel and run at $100 \mathrm{~V}$ for $90 \mathrm{~min}$. Then the proteins were transferred to a membrane using the iBlot (catalog IB1001, Life Technologies). Immediately after transfer, membranes were incubated with blocking solution containing $25 \mathrm{~g}$ of nonfat milk, TTBS (Tris- $\mathrm{NaCl}, 10 \times$, and Tween 20) for $1 \mathrm{~h}$, washed, and incubated with the rabbit anti-EphB2 antibody H-80 (1:50; sc-28980, Santa Cruz Biotechnology) or the mouse antiNR1 antibody (catalog 556308, BD Biosciences) overnight. The next day, membranes were washed with TTBS. After washing, membranes were incubated with SuperSignal West Pico Chemiluminescent Substrate (catalog 34080, Thermo Scientific) to detect the protein bands. Quantity One software from Bio-Rad was used to measure the intensity of the bands. 
Immunofluorescence assay. Rat brains were fixed in paraffin blocks and cut into $4-\mu \mathrm{m}-$ thick slices of the medial prefrontal cortex. To remove the paraffin, tissues were exposed to xylene for $15 \mathrm{~min}$. Tissues were dehydrated by immersion in ethanol $(100 \%, 95 \%, 80 \%$, and $70 \%$, respectively) for $3 \mathrm{~min}$. Tissues were washed with $10 \%$ PBS, incubated with citrateEDTA buffer, $\mathrm{pH} 6.0$, for $40 \mathrm{~min}$ at $95^{\circ} \mathrm{C}$, and allowed to stand at room temperature for 20 $\mathrm{min}$. Once the slides were dry, they were incubated with protein block for 15 min. Tissues were incubated in a moist chamber overnight at $4^{\circ} \mathrm{C}$ with the following primary antibodies: anti-tubulin $\beta$ III antibody (TU-20; 1:50; ab7751, Abcam) and anti-GFP antibody (1: 2000; ab6556, Abcam). After primary antibody incubation, tissues were washed with 10\% PBS and incubated with secondary antibodies at room temperature in a moist, dark chamber for $20 \mathrm{~min}$. The following secondary antibodies were used: Alexa Fluor 488 goat anti-rabbit IgG $\mathrm{H}+\mathrm{L}$ (1:100; A-11034, Invitrogen) and Cy5 AffiniPure donkey anti-mouse IgG $\mathrm{H}+\mathrm{L}$ (1: 100; catalog 715-175-151, Jackson ImmunoResearch). Nuclei were labeled with DAPI (D-1306; 1:50,000). Tissue images were obtained using an Olympus light microscope and merged with NIS Elements imaging software from Nikon.

Surgery. Rats were anesthetized with isoflurane and placed in a stereotaxic apparatus. Under anesthesia, the skin was retracted and holes were drilled in the skull. Rats were implanted with dual 26 gauge stainless-steel guide cannulae (Plastics One) in the mPFC as described previously (Santini et al., 2004). Stereotaxic coordinates for IL placements were $2.0 \mathrm{~mm}$ anterior, $0 \mathrm{~mm}$ lateral, and 3.6 ventral from bregma for juvenile, and $2.3 \mathrm{~mm}$ anterior, $0 \mathrm{~mm}$ lateral, and $4.4 \mathrm{~mm}$ ventral from bregma for adults (Paxinos and Watson, 1986). Coordinates for the PL placements in juvenile rats were $2.0 \mathrm{~mm}$ anterior, $0 \mathrm{~mm}$ lateral, and 2.6 ventral from bregma. Rats were allowed $7 \mathrm{~d}$ to recover from surgery.

Transfection and infusion of shRNA plasmids. SureSilencing shRNA Plasmids for EphB2 were used (KR55124G, SABiosciences). This product contained four different plasmid clones of EphB2-shRNA, each with a 21 base sequence matching different parts of the EphB2 gene sequence (Clone 1, ggaccttgtttataacatcat; Clone 2, tgacgtcgtatctcagatgat; Clone 3, cgacatctcctgtgtcaagat; Clone 4, ctactactatgaggctgattt; Scramble clone, ggaatctcattcgatgcatac). The clones were designed using a very precise algorithm (Zhou et al., 2006). BLAST analysis demonstrated that the 21 bases of all four clones only displayed $100 \%$ homology with the EphB2 gene sequence and showed no homology with other synaptic plasticity-related genes or members of the Eph family of receptors. The closest gene match to any of the clones had three base mismatches (Agbll gene to clone 1) and 2 or less base mismatches are needed for shRNA-mediated downregulation of other unintended genes (Naito et al., 2004; Kim et al., 2005). The scramble clone did not have $100 \%$ homology with any gene and the closest match had a 7 base mismatch (Erich2 gene).

All plasmids contained GFP for the identification of cells expressing the plasmids. Plasmid clones were transformed into top 10 competent cells (catalog C4040-03, Invitrogen) and then purified using the Endofree Plasmid Maxi Kit (catalog 12362, QIAGEN) following the manufacturer instructions. The EphB2-shRNA clones were mixed after normalizing their concentration. A $0.5 \mu \mathrm{g}$ sample of the plasmid clones was combined with in vivo jetPEI (catalog 201-10G, Polyplus) to enhance the transfection efficacy. In vivo jetPEI produces efficient transfection of plasmids into nondividing cells such as neurons (Hassani et al., 2005). The $0.5 \mu \mathrm{g}$ sample of the plasmids was infused into IL or PL on days 2 and 3 of the behavioral procedure before fear extinction at a rate of $0.5 \mu \mathrm{l} / \mathrm{min}$.

Statistical analysis. The percentage of time spent freezing was used as a measure of conditioned fear (Blanchard and Blanchard, 1972). Freezing is the cessation of all movements except respiration. The total time spent freezing during the $30 \mathrm{~s}$ tone was analyzed using commercial software (FreezeScan, Clever Systems). The Student's $t$ test or one-way ANOVA (STATISTICA, Statsoft) were used to analyze the behavioral and biochemical data. Following a significant main effect, post hoc tests were performed with Tukey's HSD tests. The effect of shRNA infusions on behavior were analyzed by repeated-measures ANOVA followed by pairwise comparisons with Bonferroni correction (SPSS). Values are reported as the mean \pm the SEM. The Excel-based PCR Array Data Analysis Software from the manufacturer (SABiosciences) was used to analyze the PCR array results.

\section{Results}

Identification of EphB2 in IL as a potential mediator of fear extinction in adolescent rats

To identify novel molecules critical for fear extinction-induced plasticity in IL, we first exposed a group of postnatal day 30 (P30) rats to auditory fear conditioning on day 1 and fear extinction (15 
A

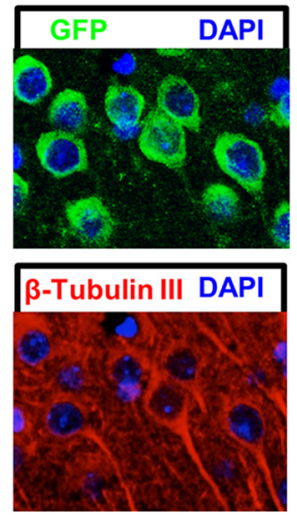

B

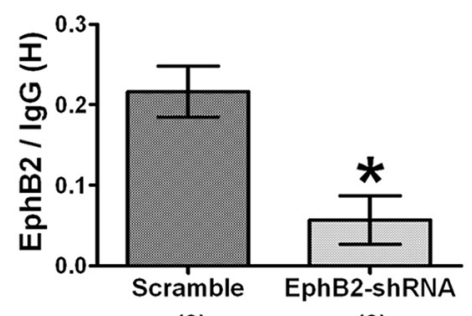

(3)

(3)

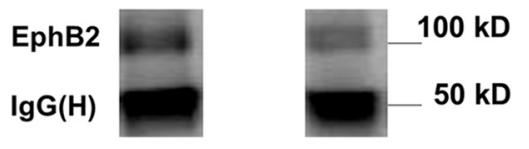

Figure 3. EphB2-shRNA plasmid is expressed in IL pyramidal neurons and reduces EphB2 protein synthesis. $\boldsymbol{A}$, Expression of plasmid GFP (green) and the neuron-specific marker $\beta$-tubulin III (red) in IL. Nuclei are stained with DAPI. B, Quantification of EphB2 protein expression $2 \mathrm{~d}$ after EphB2-shRNA or scramble-shRNA plasmid infusion (EphB2-shRNA, $n=3$; scramble-shRNA, $n=3$ ). All values are relative to $B$-actin and normalized to the average of the scramble-shRNA group. ${ }^{*} p<0.05$.

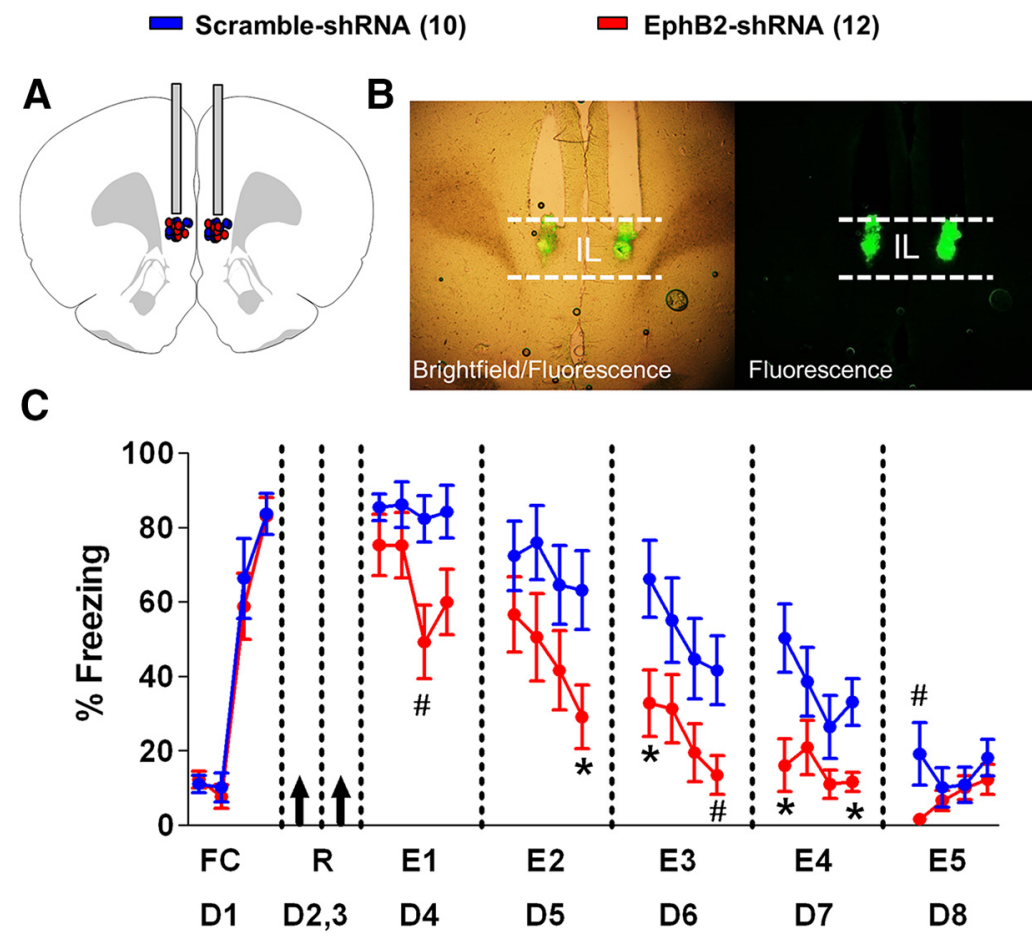

Figure 4. Reducing EphB2 synthesis in IL accelerates fear extinction. $A$, EphB2-shRNA $(n=12)$ and scramble-shRNA $(n=10)$ plasmid infusions were localized to IL. B, Expression of plasmid GFP after infusion into IL. C, Percentage of time that P30 rats spent freezing to the tone during fear conditioning (day 1 , one habituation tone plus three tone-shock pairings) and five partial extinction sessions (days $4-8$, four tones per day). Black arrows indicate the time-point of IL infusions. ${ }^{*} p \leq 0.05$; $\# p \leq 0.075$. FC, Fear conditioned; $R$, rest.

recall tones) on day 2 (Fig. $1 A, B$ ). Then, rats were separated post hoc into two groups based on their average freezing in response to the last two tones of extinction. Rats that showed $<50 \%$ freezing were placed in the normal extinction group, and rats that showed $>50 \%$ freezing were placed in the impaired extinction group. Both groups had similar levels of freezing during the last tone of conditioning $\left(t_{(7)}=2.36, p=0.39\right)$, indicating a similar acquisition of fear conditioning. Repeated-measures ANOVA of the average freezing to the first and last two tones of the normal and impaired extinction groups demonstrated a main group differ-

ence $\left(F_{(1,7)}=12.80, p<0.01\right)$ and a group by trial difference $\left(F_{(1,7)}=10.9, p=0.013\right)$. Tukey's post hoc analysis showed that although both groups had similar levels of freezing during the first two tones of extinction $(p=0.77)$, the normal extinction group froze less to the last two tones than did the impaired extinction group $(p=0.02)$, indicating that the groups differed in extinction but not fear conditioning recall.

Both groups were euthanized $5 \mathrm{~h}$ after the extinction fear conditioning. IL tissue was collected using a tissue puncher (Fig. 1C) and pooled before RNA extraction. The $5 \mathrm{~h}$ time point was chosen because increases in the expression of synaptic plasticity-related genes occur at this time point after synaptic stimulation and behavioral training (Hong et al., 2004; Lamprecht et al., 2009), and to allow time for the gene expression changes needed for consolidation of the fear extinction memory to occur. RNA was extracted from pooled IL tissue to measure the expression of synaptic plasticity-related genes with a single PCR array for each group. We calculated the fold change of different genes as the mRNA expression of the normal extinction group over the mRNA expression of the impaired extinction group. Unexpectedly, we found a 3.73-fold decrease in the IL expression of EphB2, a gene never previously associated with fear extinction, in the group showing normal extinction (Fig. 1D). Since this was a single sample for each group, we could not perform statistical analysis; however, the results provided direction for the following experiments.

\section{Fear extinction downregulates EphB2 mRNA and protein levels in IL of adolescent rats}

To confirm and extend the results of the PCR array, we measured the mRNA levels of IL EphB2 with RT-PCR in three groups of $\mathrm{P} 30$ rats (Fig. $2 A, B$ ). The COND group received 1 habituation tone and 3 toneshock pairings on day 1 and was euthanized on day 2. Rats in the fear conditioning recall $(\mathrm{CR})$ group received one habituation tone and 3 tone-shock pairings on day 1 , a conditioning recall tone on day 2 , and were euthanized $\sim 5.5 \mathrm{~h}$ later. Rats in the EXT group received 1 habituation tone and 3 tone-shock pairings on day 1 , and 15 tones on day 2 , and were euthanized $5 \mathrm{~h}$ later. We waited the additional 35 min before euthanizing the CR group to compensate for the difference in the duration of the CR (7 $\mathrm{min})$ and EXT (43 min) protocols. In addition, all euthanizations were performed at a similar time of the day (between 3:00 and 4:00 P.M. Eastern time). After being euthanized, ILs was collected for mRNA or protein analysis.

Figure $2 A$ shows the behavior of the animals used for the mRNA analysis. One-way ANOVA showed that all three groups froze similarly in response to the last tone of conditioning on day 1 (COND group, 81\%; CR group, 70\%; EXT, 76\%; $F_{(2,17)}=0.64$, $p=0.54)$. The CR and EXT groups also had levels of freezing that were similar to those of the first extinction tone on day 2 (CR group, $81 \%$; EXT group, $70 \%$; $\left.t_{(11)}=2.20, p=0.49\right)$. The EXT group showed decreased fear in response to the last tone $(21 \%)$ compared to the first tone $(70 \%)$ of extinction $\left(t_{(12)}=2.18, p=\right.$ 
0.004). RNA was extracted from IL tissue, and EphB2 mRNA was amplified using RT-PCR (Fig. 2B). B-actin and GAPDH were used as housekeeping genes (Fischer et al., 2002; Uchida et al., 2010; Wang et al., 2012; Zhan et al., 2014). An average of the $\mathrm{Ct}$ values of $\mathrm{B}$-actin and GAPDH was used to normalize EphB2 mRNA expression. One-way ANOVA showed a main group difference in IL EphB2 mRNA expression relative to $\mathrm{B}$-actin and GAPDH (COND group, 1.0; CR group, 0.8; EXT group, $\left.0.6 ; F_{(2,14)}=4.39, p=0.03\right)$. Tukey's post hoc comparisons showed that EphB2 was significantly downregulated in the EXT group compared with the COND group $(p=0.03)$. The CR group was not statistically different from the COND $(p=0.34)$ or EXT $(p=0.51)$ groups.

A one-way ANOVA of the behavioral groups used to examine EphB2 protein (Fig. 2C) showed that all three groups froze similarly to the last tone of conditioning on day 1 (COND group, 67\%; CR group, $70 \%$; EXT group, $75 \% ; F_{(2,13)}=$ $0.10, p=0.90)$. The CR and EXT groups had similar levels of freezing to the first extinction tone on day $2\left(t_{(9)}=2.26, p=\right.$ $0.68)$. The EXT group showed decreased freezing to the last tone $(41 \%)$ compared with the first tone $(73 \%)$ of extinction $\left(t_{(5)}=2.57, p=0.03\right)$. Protein was extracted from IL tissue punches, and EphB2 was immunoprecipitated and analyzed by Western blot analysis (Fig. 2D). To help control for potential differences in protein loading, we compared EphB2 expression to the IgG heavy chain [IgG $(\mathrm{H})]$ levels in each sample (Kedar et al., 2008; Liu et al., 2008; Ushijima et al., 2008). There was no main group difference in $\operatorname{IgG}(\mathrm{H})$ band density among groups $\left(F_{(2,13)}=1.42, p=0.27\right)$. One-way ANOVA showed a main group difference in IL EphB2 protein expression (COND group, 0.16; CR group, 0.11; EXT group, $\left.0.03 ; F_{(2,13)}=7.07, p=0.008\right)$. Tukey's post hoc comparisons showed that EphB2 was significantly downregulated in the EXT group compared with the COND group $(p=0.007)$ and showed a trend of being reduced compared with the CR group $(p=0.079)$, suggesting that the reduced expression of EphB2 in IL may be important for extinction memory in adolescent rats. The CR group was not different from the COND group $(p=0.45)$.

\section{Reducing EphB2 protein in IL accelerates fear extinction in} adolescent rats

To test whether reduced EphB2 expression in IL plays a role in fear extinction, plasmids containing EphB2-shRNA were infused into IL to reduce EphB2 protein levels in adolescent rats. GFP was used to detect plasmid expression. The plasmids contain promoters that allow expression in all types of cells located at the infusion site. However, EphB2 is largely expressed in presynaptic and

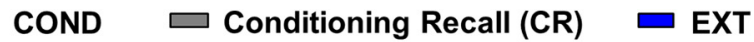

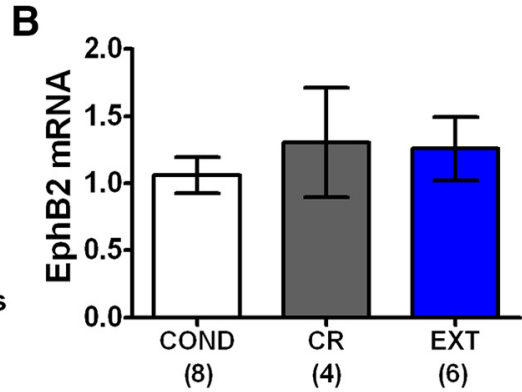

(8)

(4)

(6)
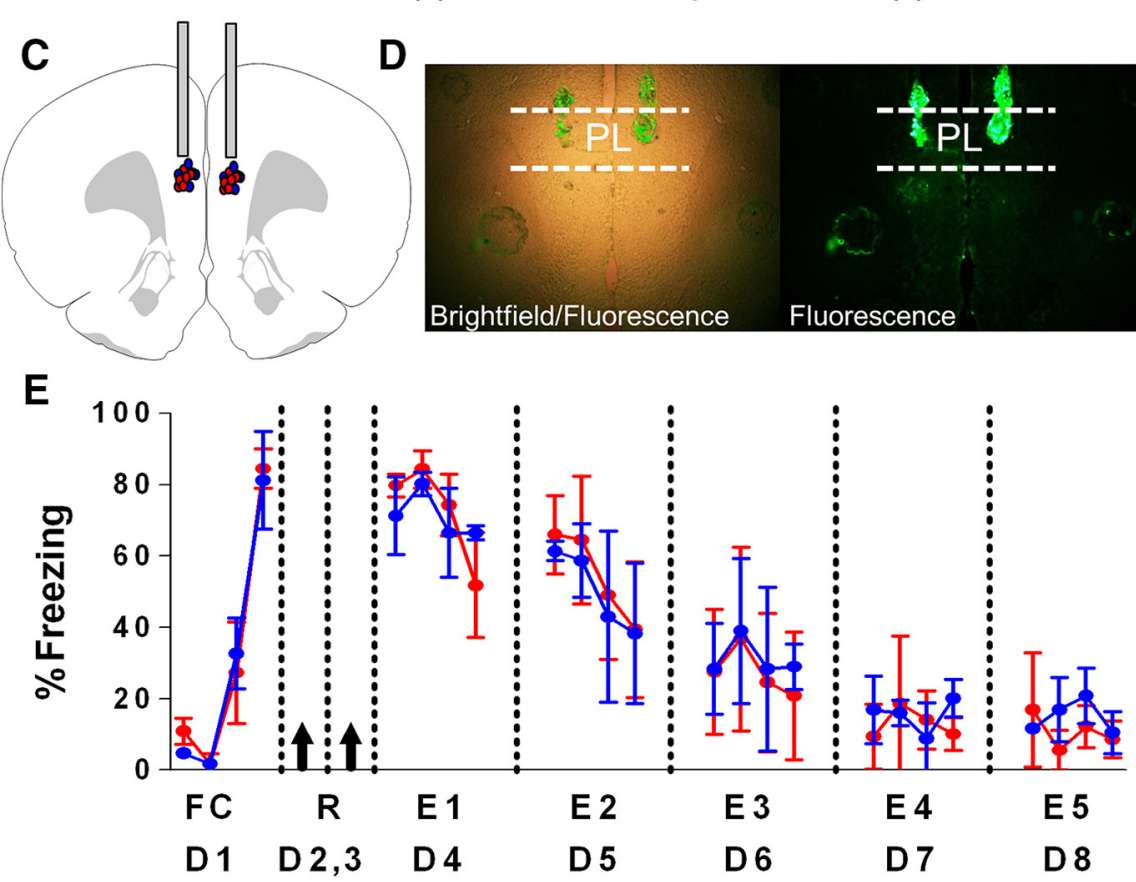

Figure 5. Reducing EphB2 synthesis in PL does not affect fear extinction. $A$, Percentage of time that $\mathrm{P} 30$ rats spent freezing to the tone during fear conditioning (day 1, 1 habituation tone plus 3 tone-shock pairings) and extinction (day 2, 15 tones). Red arrow during fear conditioning (day 1, one habituation tone plus three tone-shock pairings) and five partial extinction sessions (days $4-8$, four tones). Black arrows indicate the time point of PL infusions.

postsynaptic specializations of neurons (Liebl et al., 2003; Bouvier et al., 2008; Attwood et al., 2012), and not by astrocytes (Bundesen et al., 2003). Therefore, EphB2 expression will be mainly reduced in IL neurons by the EphB2-shRNA plasmids. To test whether EphB2-shRNA reduces EphB2 protein, the plasmids were infused into IL of adolescent rats. Two days later, animals were euthanized and the expression of plasmid GFP was verified by immunohistochemistry. IL neurons expressed GFP (Fig. 3A), indicating that they were transfected with the plasmids. In additional animals, IL tissue punches were collected $2 \mathrm{~d}$ after plasmid infusion, and EphB2 protein was analyzed by immunoprecipitation. Rats infused with EphB2-shRNA expressed less EphB2 protein in IL than rats infused with a scramble-shRNA $\left(t_{(4)}=2.78\right.$, $p=0.02$; Fig. $3 B)$. IgG $(\mathrm{H})$ did not differ between groups $\left(t_{(4)}=\right.$ $2.78, p=0.24)$. Together, these results indicate that the EphB2shRNA plasmid effectively reduces EphB2 expression in IL neurons $2 \mathrm{~d}$ after infusion. 


$$
\square \text { COND }
$$

$\square$ Conditioning Recall (CR)

EXT
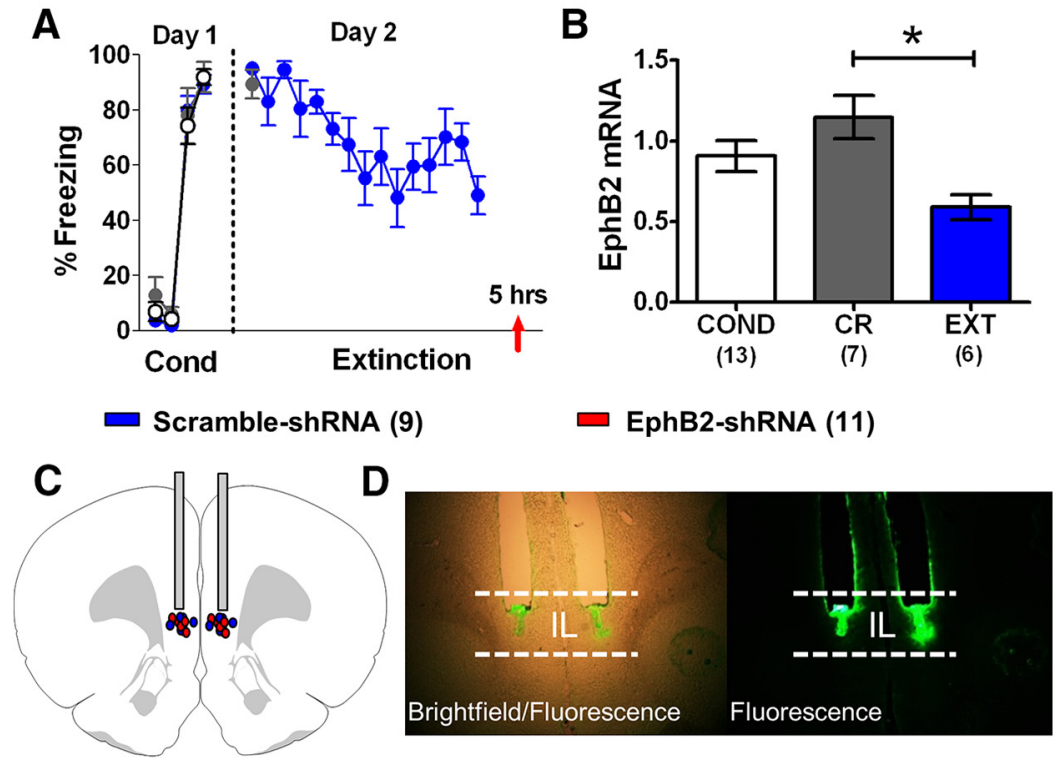

E

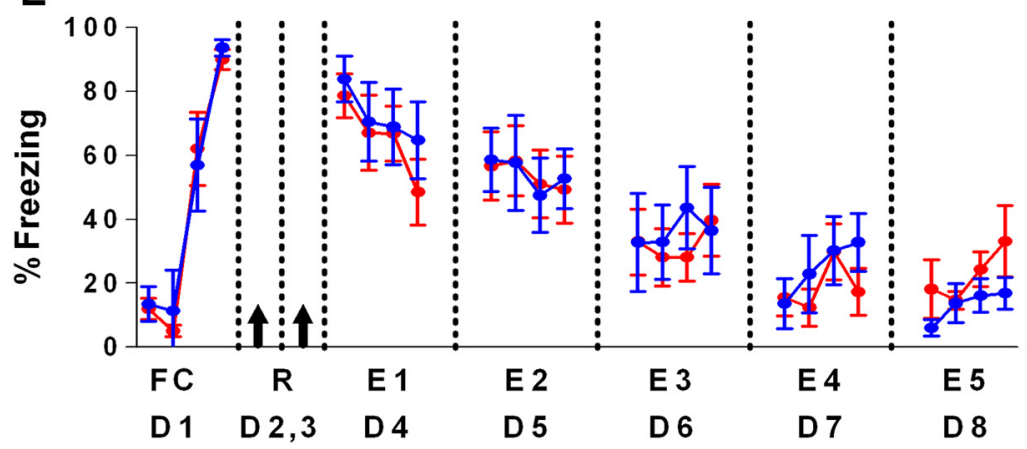

Figure 6. Reducing EphB2 synthesis in IL of adult rats does not affect fear extinction. $A$, Percentage of time that P60 rats spent freezing to the tone during fear conditioning (day 1, 1 habituation tone plus 3 tone-shock pairings) and extinction (day 2, 15 tones). Red arrow indicates the time point of euthanasia. $\boldsymbol{B}$, EphB2 mRNA expressed by each group (COND group, $n=13$; (R group, $n=7$; EXT group, $n=9)$. All values are relative to B-actin and GAPDH. C, EphB2-shRNA $(n=11)$ and scramble-shRNA $(n=9)$ plasmid infusions were localized to IL. $\boldsymbol{D}$, Expression of plasmid GFP after infusion into IL. $\boldsymbol{E}$, Percentage of time that P60 rats spent freezing to the tone during fear conditioning (day 1, 1 habituation tone plus 3 tone-shock pairings) and five partial extinction sessions (days $4-8$, four tones per day). Black arrows indicate the time point of IL infusions. ${ }^{*} p<0.05$.

Next, we tested whether reducing EphB2 protein levels in IL with the shRNA would affect fear extinction in adolescent (P30) rats. Rats received fear conditioning (one habituation tone and three tone-shock pairings) on day 1 and were separated into two groups matched for similar freezing to the last conditioning tone (EphB2-shRNA, 83\%; scramble-shRNA, $\left.83 \% ; t_{(20)}=2.09, p=0.94\right)$. On days 2 and 3 , rats were infused with plasmids containing either the EphB2-shRNA or the scramble-shRNA into IL (Fig. 4A,B). Since we hypothesized that reducing EphB2 would enhance fear extinction, we used a partial extinction protocol to increase our ability to detect facilitated extinction. From day 4 through day 8 , the rats received partial extinction [four tones per day, extinction 1 (E1) to E5]. On day 4, both groups showed similar levels of freezing to the first two tones of extinction (EphB2-shRNA, 75\%; scramble-shRNA, 86\%; $\left.t_{(20)}=2.09, p=0.26\right)$, indicating that the EphB2-shRNA did not affect the recall of the fear memory. However, the EphB2-shRNA treatment facilitated fear extinction learning across days (Fig. 4C). Repeated-measures
ANOVA showed a main group difference from E1 to E5 $\left(F_{(1,20)}=6.36, p=\right.$ $0.02)$, a main effect of tone $\left(F_{(2,19)}=\right.$ $628.2, p=0.002)$, and a tone by group effect $\left(F_{(2,19)}=276.5, p=0.004\right)$. Pairwise post hoc comparisons with Bonferroni correction showed that the EphB2-shRNA-treated rats froze less during multiple trials between the last trial of E2 and the last trial of E4 ( $p \leq$ 0.05). This finding demonstrates that reducing EphB2 expression in IL facilitates the acquisition of fear extinction.

\section{Prelimbic EphB2 is not important for fear extinction in adolescent rats} Given that the PL is adjacent to the IL and is important for fear expression (Vidal-Gonzalez et al., 2006; SierraMercado et al., 2011), we tested the possibility that the facilitation of fear extinction by the EphB2-shRNA was due to effects in PL. As shown in Figure $5 \mathrm{~A}$, we first measured the mRNA levels of PL EphB2 with RT-PCR in different groups of rats that received the same behavioral treatment used for Figure 2. One-way ANOVA showed that all three groups froze similarly to the last tone of conditioning on day 1 (COND group, 80\%; CR group, 70\%; EXT group, $81 \%$; $\left.F_{(2,18)}=0.56, p=0.57\right)$. The CR and EXT groups also had similar levels of freezing to the first extinction tone on day 2 (CR group, 81\%; EXT group, 70\%; $\left.t_{(11)}=2.20, p=0.49\right)$. The EXT group showed decreased fear to the last tone (21\%) compared the first tone $(70 \%)$ of extinction $\left(t_{(12)}=2.18, p=0.004\right)$. RNA was extracted from PL tissue, and EphB2, B-actin, and GAPDH mRNA were amplified using RT-PCR (Fig. 5B). Oneway ANOVA showed no main group difference in PL EphB2 mRNA expression relative to B-actin and GAPDH (COND group, 1.1; CR group, 1.3; EXT group, $\left.1.2 ; F_{(2,15)}=0.34, p=0.72\right)$. These results suggest that reduced EphB2 expression in PL is not needed for fear extinction.

Next, we fear conditioned two groups of rats, infused them with the same plasmids containing either the EphB2-shRNA or the scramble-shRNA into PL (Fig. 5C,D), and exposed them to the same $4 \mathrm{~d}$ extinction protocol used for the shRNA infusions into IL. Both groups were matched for freezing to the last trial of fear conditioning on day 1 (Fig. 5E). The shRNA plasmids were infused into PL on days 2 and 3, and extinction treatment ( 4 tones per day) was given on days $4-8$. Both groups showed similar extinction across days. Repeatedmeasures ANOVA showed no main group difference from E1 to $\mathrm{E} 5\left(F_{(1,15)}=0.02, p=0.88\right)$. These data indicate that reducing EphB2 expression in PL does not affect fear extinction and demonstrate a selective role of IL EphB2 in fear extinction. 


\section{IL EphB2 does not modulate fear extinction in adult rats} Until now, all of our experiments had been performed in adolescent $\mathrm{P} 30$ rats. To examine whether IL EphB2 plays a similar role in the extinction of adult animals, we conducted the same experiments in young adult P60 rats. First, we measured the mRNA levels of IL EphB2 in P60 rats with RT-PCR using the same behavioral groups as shown in Figure 2. As shown in Figure 6A, one-way ANOVA showed that all three groups froze similarly to the last tone of conditioning on day 1 (COND group, 92\%; CR group, 92\%; EXT group, $\left.84 \% ; F_{(2,26)}=0.74, p=0.49\right)$. The $\mathrm{CR}$ and EXT groups also had similar levels of freezing to the first extinction tone on day 2 (CR group, 89\%; EXT group, 94\%; $\left.t_{(13)}=2.16, p=0.46\right)$. The EXT group showed decreased fear to the last tone $(53 \%)$ compared the first tone $(94 \%)$ of extinction $\left(t_{(16)}=2.11, p<0.001\right)$. RNA was extracted from IL tissue, and EphB2, B-actin, and GAPDH mRNA were amplified using RTPCR (Fig. 6B). One-way ANOVA showed a main group difference in IL EphB2 mRNA expression relative to B-actin and GAPDH (COND group, 0.9; CR group, 1.1; EXT group, 0.6; $\left.F_{(2,23)}=4.90, p=0.02\right)$. Tukey's post hoc comparisons showed that EphB2 was significantly downregulated in the EXT group compared with the CR group ( $p=0.01$ ), but not the COND group ( $p=0.13$ ), suggesting that reduced expression of EphB2 in IL may not be important for extinction memory in adult rats.

Next, we fear conditioned two groups of P60 rats and matched them for freezing to the last trial of fear conditioning on day 1 . On days 2 and 3, the groups were infused with the same plasmid containing either the EphB2-shRNA or the scramble-shRNA into IL (Fig. 6C,D). Both groups received extinction (four tones per day) on days 4-8 and showed similar extinction across days (Fig. $6 E)$. Repeated-measures ANOVA showed no main group difference from $\mathrm{E} 1$ to $\mathrm{E} 5\left(F_{(1,18)}=0.06, p=0.80\right)$. These data indicate that reducing EphB2 expression in IL of adult rats (P60) does not affect fear extinction and demonstrate a selective role of IL EphB2 in adolescent fear extinction.

\section{Discussion}

The main findings of this study are that the tyrosine kinase EphB2 is downregulated in IL $5 \mathrm{~h}$ after fear extinction, that reducing EphB2 synthesis in IL enhances fear extinction, and that this mechanism regulates fear extinction in adolescent rats but not in adult rats. Although EphB2 plays a role in synaptic plasticity (Dalva et al., 2000; Grunwald et al., 2001; Takasu et al., 2002; Lai and Ip, 2009; Antion et al., 2010; Hruska and Dalva, 2012) and spatial memory (Cissé et al., 2011), this is the first demonstration that EphB2 modulates emotional learning and memory. Interestingly, our findings suggest that EphB2 may play a more critical role in memory formation during development. Fear extinction memory requires NMDAR activation in both adolescent and adult rodents (Santini et al., 2001; Burgos-Robles et al., 2007; Sotres-Bayon et al., 2007; McCallum et al., 2010). Our finding that EphB2 in IL facilitates fear extinction only in adolescent rats suggests that additional signaling mechanisms appear to be mediating extinction memory in adolescence. In the following paragraphs, we discuss possible mechanisms by which IL EphB2 downregulation could be driving fear extinction in adolescence (Fig. 7).

The Ephrin receptors (EphRs) are a large family of receptor tyrosine kinases composed of the EphA and EphB receptors, which bind with promiscuity to their natural ligands, Ephrin A and Ephrin B (Gale et al., 1996; Pasquale, 2004). During brain development, EphRs modulate axonal growth and pruning (Gao et al., 1999; Cramer et al., 2006). These developmental processes continue in the prefrontal cortex until late adolescence (Cress-

\section{Fear Extinction}
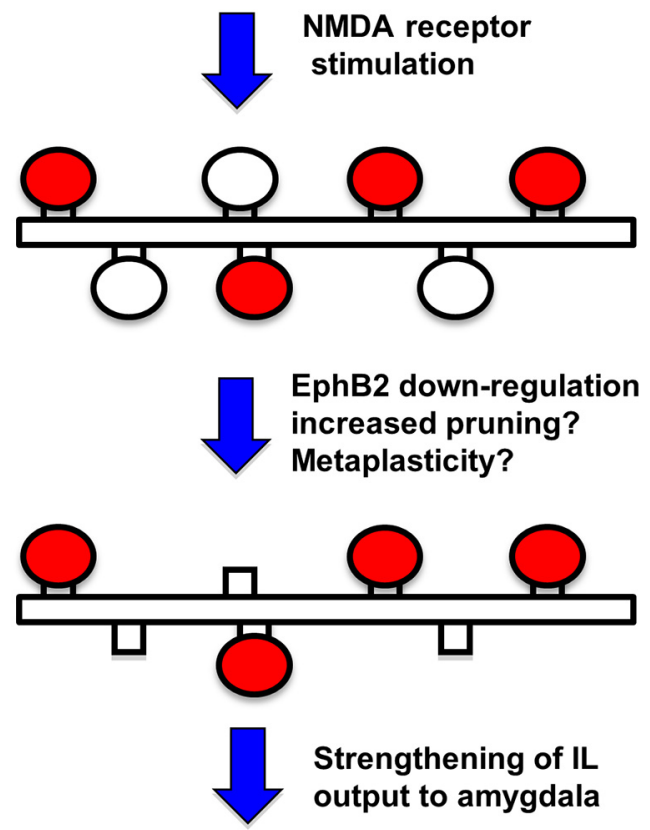

Reduced Fear

Figure 7. Model of the role of EphB2-mediated IL plasticity in fear extinction during adolescence. NMDA receptor stimulation during fear extinction potentiates extinction-related synapses (shown in red) and causes reduced EphB2 expression in IL. Reduced EphB2 may eliminate synapses not required for fear extinction (white ovals) while reducing the depotentiation of extinction-related synapses. The increase in signal-to-noise ratio would strengthen ILmediated inhibition of the amygdala to reduce fear.

man et al., 2010), and may contribute to altered fear conditioning and extinction at this age (McCallum et al., 2010; Pattwell et al., 2011; Hartley and Lee, 2015). Synaptic pruning is believed to preserve activated behaviorally important synapses while eliminating unused weaker synapses, leading to maturation of prefrontal functions (Katz and Shatz, 1996; Kano and Hashimoto, 2009). Since decreasing the expression of EphB2 reduces the density of dendritic spines (Kayser et al., 2006, 2011), the reduced expression of EphB2 after extinction may lead to the pruning of synapses that are not involved in fear extinction memory, perhaps via interactions with glia (Schafer and Stevens, 2013). In fact, the disruption of synaptic pruning can impair learning (Zhan et al., 2014). Therefore, EphB2-mediated pruning of IL synapses may be required for fear extinction during adolescence. The lower prefrontal synaptic pruning found in adults may restrict this EphB2-mediated mechanism to adolescents.

EphB2 is also known to play a role in synaptic plasticity by controlling the activity of AMPA and NMDA receptors (ShefflerCollins and Dalva, 2012). Ephrin-mediated EphB2 activation increases EphB2-NMDA interaction and NMDA receptor potentiation (Dalva et al., 2000; Henderson et al., 2001; Takasu et al., 2002). EphB2 receptors also promote NMDA receptor clustering and synaptic localization (Nolt et al., 2011) and can activate NMDA receptors via Src phosphorylation (Takasu et al., 2002). Decreasing EphB2 expression reduces NMDA receptor currents (Henderson et al., 2001; Cissé et al., 2011). Therefore, the reduced expression of EphB2 after extinction would likely reduce NMDA-dependent plasticity in IL. At first glance, this seems counterintuitive given that fear extinction depends on 
NMDA-dependent plasticity in the prefrontal cortex (BurgosRobles et al., 2007). However, the NMDA receptor dependency of fear extinction ends $<2 \mathrm{~h}$ after fear extinction (Burgos-Robles et al., 2007). In addition, synapses from many structures show metaplasticity and are resistant to LTP after learning because they are presumed to be already potentiated (Sacchetti et al., 2002; Tsvetkov et al., 2002; Whitlock et al., 2006; Zhu et al., 2007). Furthermore, potentiated synapses are more susceptible to NMDA receptor-dependent LTP reversal (Norris et al., 1998). After extinction, IL synapses that were potentiated by extinction training may downregulate EphB2 to avoid LTP reversal and maintain the extinction memory. Consistent with this, LTP in the $\mathrm{mPFC}$ is associated with the maintenance of extinction (Herry and Garcia, 2002).

Different mechanisms appear to mediate fear extinction in preadolescent $(<\mathrm{P} 24)$, adolescent $(\sim \mathrm{P} 30-\mathrm{P} 45)$, and adult ( $>$ P60) rats (Callaghan and Richardson, 2013). During the early preadolescent phase, fear extinction erases fear memories via NMDA receptor-independent mechanisms that do not require the mPFC (Langton et al., 2007; Kim et al., 2009). As the preadolescent phase progresses, chondroitin sulfate proteoglycans organize into perineural nets in the amygdala and fear memories become resistant to erasure by extinction (Gogolla et al., 2009). From this stage through to adulthood, extinction instead creates a new memory that inhibits the expression of the intact fear memory (Quirk et al., 2010) through a NMDA receptordependent mechanism that involves ERK signaling in IL (Hugues et al., 2004; Burgos-Robles et al., 2007; Langton et al., 2007; Kim et al., 2009). However, adolescent rats require more extinction training and NMDA receptor activation than adult rats to successfully recall extinction memory, suggesting the presence of a break in adolescent extinction memory (McCallum et al., 2010). Since EphB2 expression impeded extinction memory in adolescent rats, but not in adult rats, EphB2 may contribute to this break in extinction.

Which molecular mechanism mediates EphB2 downregulation? A recent study (Dias et al., 2014) found that miR-134a downregulates the Notch signaling pathway $6 \mathrm{~h}$ after fear conditioning in the amygdala. EphB2 is downregulated by miR-128 (Lin et al., 2013). miR-128 modulates neuronal excitability and motor behavior (Tan et al., 2013) and is increased in the hippocampus $3 \mathrm{~h}$ after contextual fear conditioning in an NMDA receptor-dependent manner (Kye et al., 2011). Furthermore, an increase in miR-128 in IL after fear extinction contributes to fear extinction memory (Lin et al., 2011). Therefore, the observed decrease in EphB2 in IL after fear extinction could be produced by an NMDA receptor-dependent increase in miRNAs such as miR-128.

Our findings demonstrate the importance of the tyrosine kinase receptor EphB2 in fear extinction during adolescence. Previous research shows that inappropriate expression of EphB2 in different brain structures may play an important role in CNS diseases. Increased expression of EphB2 in the amygdala leads to anxiety in mice (Attwood et al., 2011), whereas too little hippocampal EphB2 is associated with impaired cognitive function in an Alzheimer mouse model (Cissé et al., 2011). In addition, fear conditioning increases the hippocampal expression of one of the EphB2 ligands, Ephrin B2, suggesting that EphB2 may play a role in fear learning (Trabalza et al., 2012). Our study extends previous research by directly demonstrating that manipulating EphB2 expression alters emotional learning and memory.

Furthermore, our results indicate that different or additional mechanisms mediate fear extinction in adolescents. Identifying drug treatments aimed at specific targets such as EphB2 could enhance exposure therapy during adolescence. The facilitation of exposure therapy during adolescence may reduce the likelihood of the development of PTSD after similar traumatic exposure in adulthood (Koenen et al., 2007). Therefore, understanding extinction during adolescent could be a key strategy in battling PTSD in adults.

\section{References}

Ahrens J, Rexford L (2002) Cognitive processing therapy for incarcerated adolescents with PTSD. J Aggress Maltreat Trauma 6:201-216. CrossRef

Antion MD, Christie LA, Bond AM, Dalva MB, Contractor A (2010) Ephrin-B3 regulates glutamate receptor signaling at hippocampal synapses. Mol Cell Neurosci 45:378-388. CrossRef Medline

Attwood BK, Bourgognon JM, Patel S, Mucha M, Schiavon E, Skrzypiec AE, Young KW, Shiosaka S, Korostynski M, Piechota M, Przewlocki R, Pawlak R (2011) Neuropsin cleaves EphB2 in the amygdala to control anxiety. Nature 473:372-375. CrossRef Medline

Attwood BK, Patel S, Pawlak R (2012) Ephs and ephrins: emerging therapeutic targets in neuropathology. Int J Biochem Cell Biol 44:578-581. CrossRef Medline

Berger R, Gelkopf M (2009) School-based intervention for the treatment of tsunami-related distress in children: a quasi-randomized controlled trial. Psychother Psychosom 78:364-371. CrossRef Medline

Berger R, Pat-Horenczyk R, Gelkopf M (2007) School-based intervention for prevention and treatment of elementary-students' terror-related distress in Israel: a quasi-randomized controlled trial. J Trauma Stress 20: 541-551. CrossRef Medline

Blanchard DC, Blanchard RJ (1972) Innate and conditioned reactions to threat in rats with amygdaloid lesions. J Comp Physiol Psychol 81:281290. CrossRef Medline

Bouvier D, Corera AT, Tremblay ME, Riad M, Chagnon M, Murai KK, Pasquale EB, Fon EA, Doucet G (2008) Pre-synaptic and post-synaptic localization of EphA4 and EphB2 in adult mouse forebrain. J Neurochem 106:682-695. CrossRef Medline

Bundesen LQ, Scheel TA, Bregman BS, Kromer LF (2003) Ephrin-B2 and EphB2 regulation of astrocyte-meningeal fibroblast interactions in response to spinal cord lesions in adult rats. J Neurosci 23:7789-7800. Medline

Burgos-Robles A, Vidal-Gonzalez I, Santini E, Quirk GJ (2007) Consolidation of fear extinction requires NMDA receptor-dependent bursting in the ventromedial prefrontal cortex. Neuron 53:871-880. CrossRef Medline

Callaghan BL, Richardson R (2013) Early experiences and the development of emotional learning systems in rats. Biol Mood Anxiety Disord 3:8. CrossRef Medline

Cissé M, Halabisky B, Harris J, Devidze N, Dubal DB, Sun B, Orr A, Lotz G, Kim DH, Hamto P, Ho K, Yu GQ, Mucke L (2011) Reversing EphB2 depletion rescues cognitive functions in Alzheimer model. Nature 469: 47-52. CrossRef Medline

Cramer KS, Cerretti DP, Siddiqui SA (2006) EphB2 regulates axonal growth at the midline in the developing auditory brainstem. Dev Biol 295:76-89. CrossRef Medline

Cressman VL, Balaban J, Steinfeld S, Shemyakin A, Graham P, Parisot N, Moore H (2010) Prefrontal cortical inputs to the basal amygdala undergo pruning during late adolescence in the rat. J Comp Neurol 518: 2693-2709. CrossRef Medline

Dalva MB, Takasu MA, Lin MZ, Shamah SM, Hu L, Gale NW, Greenberg ME (2000) EphB receptors interact with NMDA receptors and regulate excitatory synapse formation. Cell 103:945-956. CrossRef Medline

Dias BG, Goodman JV, Ahluwalia R, Easton AE, Andero R, Ressler KJ (2014) Amygdala-dependent fear memory consolidation via miR-34a and notch signaling. Neuron 83:906-918. CrossRef Medline

Elowe S, Holland SJ, Kulkarni S, Pawson T (2001) Downregulation of the Ras-mitogen-activated protein kinase pathway by the EphB2 receptor tyrosine kinase is required for ephrin-induced neurite retraction. Mol Cell Biol 21:7429-7441. CrossRef Medline

Fischer A, Sananbenesi F, Schrick C, Spiess J, Radulovic J (2002) Cyclindependent kinase 5 is required for associative learning. J Neurosci 22: 3700-3707. Medline

Flanagan JG, Vanderhaeghen P (1998) The ephrins and Eph receptors in neural development. Annu Rev Neurosci 21:309-345. CrossRef Medline 
Fontanez-Nuin DE, Santini E, Quirk GJ, Porter JT (2011) Memory for fear extinction requires mGluR5-mediated activation of infralimbic neurons. Cereb Cortex 21:727-735. CrossRef Medline

Gale NW, Holland SJ, Valenzuela DM, Flenniken A, Pan L, Ryan TE, Henkemeyer M, Strebhardt K, Hirai H, Wilkinson DG, Pawson T, Davis S, Yancopoulos GD (1996) Eph receptors and ligands comprise two major specificity subclasses and are reciprocally compartmentalized during embryogenesis. Neuron 17:9-19. CrossRef Medline

Gao PP, Yue Y, Cerretti DP, Dreyfus C, Zhou R (1999) Ephrin-dependent growth and pruning of hippocampal axons. Proc Natl Acad Sci U S A 96:4073-4077. CrossRef Medline

Gilboa-Schechtman E, Foa EB, Shafran N, Aderka IM, Powers MB, Rachamim L, Rosenbach L, Yadin E, Apter A (2010) Prolonged exposure versus dynamic therapy for adolescent PTSD: a pilot randomized controlled trial. J Am Acad Child Adolesc Psychiatry 49:1034-1042. CrossRef Medline

Gogolla N, Caroni P, Lüthi A, Herry C (2009) Perineuronal nets protect fear memories from erasure. Science 325:1258-1261. CrossRef Medline

Grunwald IC, Korte M, Wolfer D, Wilkinson GA, Unsicker K, Lipp HP, Bonhoeffer T, Klein R (2001) Kinase-independent requirement of EphB2 receptors in hippocampal synaptic plasticity. Neuron 32:10271040. CrossRef Medline

Hartley CA, Lee FS (2015) Sensitive periods in affective development: nonlinear maturation of fear learning. Neuropsychopharmacology 40:50-60. CrossRef Medline

Hassani Z, Lemkine GF, Erbacher P, Palmier K, Alfama G, Giovannangeli C, Behr JP, Demeneix BA (2005) Lipid-mediated siRNA delivery downregulates exogenous gene expression in the mouse brain at picomolar levels. J Gene Med 7:198-207. CrossRef Medline

Henderson JT, Georgiou J, Jia Z, Robertson J, Elowe S, Roder JC, Pawson T (2001) The receptor tyrosine kinase EphB2 regulates NMDA-dependent synaptic function. Neuron 32:1041-1056. CrossRef Medline

Herry C, Garcia R (2002) Prefrontal cortex long-term potentiation, but not long-term depression, is associated with the maintenance of extinction of learned fear in mice. J Neurosci 22:577-583. Medline

Hong SJ, Li H, Becker KG, Dawson VL, Dawson TM (2004) Identification and analysis of plasticity-induced late-response genes. Proc Natl Acad Sci U S A 101:2145-2150. CrossRef Medline

Hruska M, Dalva MB (2012) Ephrin regulation of synapse formation, function and plasticity. Mol Cell Neurosci 50:35-44. CrossRef Medline

Hugues S, Deschaux O, Garcia R (2004) Postextinction infusion of a mitogen-activated protein kinase inhibitor into the medial prefrontal cortex impairs memory of the extinction of conditioned fear. Learn Mem 11:540-543. CrossRef Medline

Hugues S, Chessel A, Lena I, Marsault R, Garcia R (2006) Prefrontal infusion of PD098059 immediately after fear extinction training blocks extinction-associated prefrontal synaptic plasticity and decreases prefrontal ERK2 phosphorylation. Synapse 60:280-287. CrossRef Medline

Kano M, Hashimoto K (2009) Synapse elimination in the central nervous system. Curr Opin Neurobiol 19:154-161. CrossRef Medline

Katz LC, Shatz CJ (1996) Synaptic activity and the construction of cortical circuits. Science 274:1133-1138. CrossRef Medline

Kayser MS, McClelland AC, Hughes EG, Dalva MB (2006) Intracellular and trans-synaptic regulation of glutamatergic synaptogenesis by EphB receptors. J Neurosci 26:12152-12164. CrossRef Medline

Kayser MS, Nolt MJ, Dalva MB (2008) EphB receptors couple dendritic filopodia motility to synapse formation. Neuron 59:56-69. CrossRef Medline

Kayser MS, Lee AC, Hruska M, Dalva MB (2011) Preferential control of basal dendritic protrusions by EphB2. PLoS One 6:e17417. CrossRef Medline

Kedar PS, Stefanick DF, Horton JK, Wilson SH (2008) Interaction between PARP-1 and ATR in mouse fibroblasts is blocked by PARP inhibition. DNA Repair (Amst) 7:1787-1798. CrossRef Medline

Kim DH, Behlke MA, Rose SD, Chang MS, Choi S, Rossi JJ (2005) Synthetic dsRNA dicer substrates enhance RNAi potency and efficacy. Nat Biotechnol 23:222-226. CrossRef Medline

Kim JH, Hamlin AS, Richardson R (2009) Fear extinction across development: the involvement of the medial prefrontal cortex as assessed by temporary inactivation and immunohistochemistry. J Neurosci 29: 10802-10808. CrossRef Medline

Kim JH, Li S, Richardson R (2011) Immunohistochemical analyses of long- term extinction of conditioned fear in adolescent rats. Cereb Cortex 21: 530-538. CrossRef Medline

Koenen KC, Moffitt TE, Poulton R, Martin J, Caspi A (2007) Early childhood factors associated with the development of post-traumatic stress disorder: results from a longitudinal birth cohort. Psychol Med 37:181192. CrossRef Medline

Kye MJ, Neveu P, Lee YS, Zhou M, Steen JA, Sahin M, Kosik KS, Silva AJ (2011) NMDA mediated contextual conditioning changes miRNA expression. PLoS One 6:e24682. CrossRef Medline

Lai KO, Ip NY (2009) Synapse development and plasticity: roles of ephrin/ Eph receptor signaling. Curr Opin Neurobiol 19:275-283. CrossRef Medline

Lamprecht R, Dracheva S, Assoun S, LeDoux JE (2009) Fear conditioning induces distinct patterns of gene expression in lateral amygdala. Genes Brain Behav 8:735-743. CrossRef Medline

Langton JM, Kim JH, Nicholas J, Richardson R (2007) The effect of the NMDA receptor antagonist MK-801 on the acquisition and extinction of learned fear in the developing rat. Learn Mem 14:665-668. CrossRef Medline

Liebl DJ, Morris CJ, Henkemeyer M, Parada LF (2003) mRNA expression of ephrins and Eph receptor tyrosine kinases in the neonatal and adult mouse central nervous system. J Neurosci Res 71:7-22. CrossRef Medline

Lin L, Chen X, Peng X, Zhou J, Kung HF, Lin MC, Jiang S (2013) MicroRNA-128 promotes cell-cell adhesion in U87 glioma cells via regulation of EphB2. Oncol Rep 30:1239-1248. CrossRef Medline

Lin Q, Wei W, Coelho CM, Li X, Baker-Andresen D, Dudley K, Ratnu VS, Boskovic Z, Kobor MS, Sun YE, Bredy TW (2011) The brain-specific microRNA miR-128b regulates the formation of fear-extinction memory. Nat Neurosci 14:1115-1117. CrossRef Medline

Liu L, Chen L, Chung J, Huang S (2008) Rapamycin inhibits F-actin reorganization and phosphorylation of focal adhesion proteins. Oncogene 27:4998-5010. CrossRef Medline

Mahan AL, Ressler KJ (2012) Fear conditioning, synaptic plasticity and the amygdala: implications for posttraumatic stress disorder. Trends Neurosci 35:24-35. CrossRef Medline

Maren S, Phan KL, Liberzon I (2013) The contextual brain: implications for fear conditioning, extinction and psychopathology. Nat Rev Neurosci 14:417-428. CrossRef Medline

McCallum J, Kim JH, Richardson R (2010) Impaired extinction retention in adolescent rats: effects of D-cycloserine. Neuropsychopharmacology 35 : 2134-2142. CrossRef Medline

McClelland AC, Hruska M, Coenen AJ, Henkemeyer M, Dalva MB (2010) Trans-synaptic EphB2-ephrin-B3 interaction regulates excitatory synapse density by inhibition of postsynaptic MAPK signaling. Proc Natl Acad Sci U S A 107:8830-8835. CrossRef Medline

Naito Y, Yamada T, Ui-Tei K, Morishita S, Saigo K (2004) siDirect: highly effective, target-specific siRNA design software for mammalian RNA interference. Nucleic Acids Res 32:W124-W129. CrossRef Medline

Nishimura T, Yamaguchi T, Tokunaga A, Hara A, Hamaguchi T, Kato K, Iwamatsu A, Okano H, Kaibuchi K (2006) Role of numb in dendritic spine development with a Cdc42 GEF intersectin and EphB2. Mol Biol Cell 17:1273-1285. CrossRef Medline

Nolt MJ, Lin Y, Hruska M, Murphy J, Sheffler-Colins SI, Kayser MS, Passer J, Bennett MV, Zukin RS, Dalva MB (2011) EphB controls NMDA receptor function and synaptic targeting in a subunit-specific manner. J Neurosci 31:5353-5364. CrossRef Medline

Norris CM, Halpain S, Foster TC (1998) Reversal of age-related alterations in synaptic plasticity by blockade of L-type $\mathrm{Ca}^{2+}$ channels. J Neurosci 18:3171-3179. Medline

Pasquale EB (2004) Eph-ephrin promiscuity is now crystal clear. Nat Neurosci 7:417-418. CrossRef Medline

Pattwell SS, Bath KG, Casey BJ, Ninan I, Lee FS (2011) Selective earlyacquired fear memories undergo temporary suppression during adolescence. Proc Natl Acad Sci U S A 108:1182-1187. CrossRef Medline

Pattwell SS, Duhoux S, Hartley CA, Johnson DC, Jing D, Elliott MD, Ruberry EJ, Powers A, Mehta N, Yang RR, Soliman F, Glatt CE, Casey BJ, Ninan I, Lee FS (2012) Altered fear learning across development in both mouse and human. Proc Natl Acad Sci U S A 109:16318-16323. CrossRef Medline

Paxinos G, Watson C (1986) The rat brain in stereotaxic coordinates. San Diego, CA: Academic. 
Quirk GJ, Mueller D (2008) Neural mechanisms of extinction learning and retrieval. Neuropsychopharmacology 33:56-72. CrossRef Medline

Quirk GJ, Paré D, Richardson R, Herry C, Monfils MH, Schiller D, Vicentic A (2010) Erasing fear memories with extinction training. J Neurosci 30: 14993-14997. CrossRef Medline

Sacchetti B, Lorenzini CA, Baldi E, Bucherelli C, Roberto M, Tassoni G, Brunelli M (2002) Time-dependent inhibition of hippocampal LTP in vitro following contextual fear conditioning in the rat. Eur J Neurosci 15:143-150. CrossRef Medline

Santini E, Muller RU, Quirk GJ (2001) Consolidation of extinction learning involves transfer from NMDA-independent to NMDA-dependent memory. J Neurosci 21:9009-9017. Medline

Santini E, Ge H, Ren K, Peña de Ortiz S, Quirk GJ (2004) Consolidation of fear extinction requires protein synthesis in the medial prefrontal cortex. J Neurosci 24:5704-5710. CrossRef Medline

Schafer DP, Stevens B (2013) Phagocytic glial cells: sculpting synaptic circuits in the developing nervous system. Curr Opin Neurobiol 23:10341040. CrossRef Medline

Sepulveda-Orengo MT, Lopez AV, Soler-Cedeño O, Porter JT (2013) Fear extinction induces mGluR5-mediated synaptic and intrinsic plasticity in infralimbic neurons. J Neurosci 33:7184-7193. CrossRef Medline

Sheffler-Collins SI, Dalva MB (2012) EphBs: an integral link between synaptic function and synaptopathies. Trends Neurosci 35:293-304. CrossRef Medline

Sierra-Mercado D, Padilla-Coreano N, Quirk GJ (2011) Dissociable roles of prelimbic and infralimbic cortices, ventral hippocampus, and basolateral amygdala in the expression and extinction of conditioned fear. Neuropsychopharmacology 36:529-538. CrossRef Medline

Sotres-Bayon F, Bush DE, LeDoux JE (2007) Acquisition of fear extinction requires activation of NR2B-containing NMDA receptors in the lateral amygdala. Neuropsychopharmacology 32:1929-1940. CrossRef Medline

Sotres-Bayon F, Diaz-Mataix L, Bush DE, LeDoux JE (2009) Dissociable roles for the ventromedial prefrontal cortex and amygdala in fear extinction: NR2B contribution. Cereb Cortex 19:474-482. CrossRef Medline

Srivastava N, Robichaux MA, Chenaux G, Henkemeyer M, Cowan CW (2013) EphB2 receptor forward signaling controls cortical growth cone collapse via Nck and Pak. Mol Cell Neurosci 52:106-116. CrossRef Medline

Takasu MA, Dalva MB, Zigmond RE, Greenberg ME (2002) Modulation of NMDA receptor-dependent calcium influx and gene expression through EphB receptors. Science 295:491-495. CrossRef Medline
Tan CL, Plotkin JL, Venø MT, von Schimmelmann M, Feinberg P, Mann S, Handler A, Kjems J, Surmeier DJ, O'Carroll D, Greengard P, Schaefer A (2013) MicroRNA-128 governs neuronal excitability and motor behavior in mice. Science 342:1254-1258. CrossRef Medline

Trabalza A, Colazingari S, Sgobio C, Bevilacqua A (2012) Contextual learning increases dendrite complexity and EphrinB2 levels in hippocampal mouse neurons. Behav Brain Res 227:175-183. CrossRef Medline

Tsvetkov E, Carlezon WA, Benes FM, Kandel ER, Bolshakov VY (2002) Fear conditioning occludes LTP-induced presynaptic enhancement of synaptic transmission in the cortical pathway to the lateral amygdala. Neuron 34:289-300. CrossRef Medline

Uchida S, Hara K, Kobayashi A, Funato H, Hobara T, Otsuki K, Yamagata H, McEwen BS, Watanabe Y (2010) Early life stress enhances behavioral vulnerability to stress through the activation of REST4-mediated gene transcription in the medial prefrontal cortex of rodents. J Neurosci 30: 15007-15018. CrossRef Medline

Ushijima Y, Koshizuka T, Goshima F, Kimura H, Nishiyama Y (2008) Herpes simplex virus type 2 UL56 interacts with the ubiquitin ligase Nedd4 and increases its ubiquitination. J Virol 82:5220-5233. CrossRef Medline

Vidal-Gonzalez I, Vidal-Gonzalez B, Rauch SL, Quirk GJ (2006) Microstimulation reveals opposing influences of prelimbic and infralimbic cortex on the expression of conditioned fear. Learn Mem 13:728-733. CrossRef Medline

Wang WS, Kang S, Liu WT, Li M, Liu Y, Yu C, Chen J, Chi ZQ, He L, Liu JG (2012) Extinction of aversive memories associated with morphine withdrawal requires ERK-mediated epigenetic regulation of brain-derived neurotrophic factor transcription in the rat ventromedial prefrontal cortex. J Neurosci 32:13763-13775. CrossRef Medline

Whitlock JR, Heynen AJ, Shuler MG, Bear MF (2006) Learning induces long-term potentiation in the hippocampus. Science 313:1093-1097. CrossRef Medline

Zhan Y, Paolicelli RC, Sforazzini F, Weinhard L, Bolasco G, Pagani F, Vyssotski AL, Bifone A, Gozzi A, Ragozzino D, Gross CT (2014) Deficient neuron-microglia signaling results in impaired functional brain connectivity and social behavior. Nat Neurosci 17:400-406. CrossRef Medline

Zhou H, Zeng X, Wang Y, Seyfarth BR (2006) A three-phase algorithm for computer aided siRNA design. Informatica 30:357-364.

Zhu L, Scelfo B, Hartell NA, Strata P, Sacchetti B (2007) The effects of fear conditioning on cerebellar LTP and LTD. Eur J Neurosci 26:219-227. CrossRef Medline 